ЗМІСТОВІ ЗАСАДИ ФОРМУВАННЯ ДІЄСЛІВНОЇ ЛЕКСИКИ В ДОШКІЛЬНИКІВ ІЗ ЗАГАЛЬНИМ НЕДОРОЗИВНЕННЯМ МОВЛЕННЯ

\title{
FORMATION OF VERBAL VOCABULARY IN PRESCHOOLERS WITH GENERAL SPEECH UNDEVELOPMENT: PRINCIPLES OF CONTENTS
}

Статтю присвячено проблемі фрормування дієслівної ланки лексичного компоненту в дошкільників із загальним недорозвиненням мовлення, зокрема розробленню змістовометодичних аспектів логопедичної роботи щодо нормалізації дієслівної лексики. Наголошено на значенні дієслівної лексики для розвитку смислових компонентів мовлення, синтаксичних структур та змістовності дитячого мовлення. Визначено типові особливості опанування дієслівної лексики дітьми з мовленнєвим недорозвитком: порушення розрізнення семантико-граматичних форм дієслів, ситуативні вербальні та жестові заміни дієслів, звуження семантичного поля дієслів, труднощі реалізації синтаксичних зв'язків дієслів у висловлюваннях. Проаналізовано сучасні критерії діагностики словника дітей із загальним недорозвиненням мовлення та конкретизовано їхній зміст стосовно дієслівної лексики; зазначено про важливість оцінки сфрормованості у дітей граматичних форм дієслів (родових, видових, ін.), семантичних (пресріксальних, сусріксальних), лексико-семантичних форм дієслівної синонімії, антонімії, багатозначності, ін.; навичок лексичного контролю у прочесі вживання дієслів.

Розроблено змістові засади роботи з фрормування дієслівної лексики у дошкільників із загальним недорозвиненням мовлення, зокрема: накопичення дієслівних лексем 3 урахуванням граматичної категоріальності дієслова як частини мови; розвиток розуміння і використання дериваційних значень дієслів, зумовлених словотворчими морфемами; формування лексико-семантичних форм дієслова; формування операцій лексичного контролю на морфологічному та смисловому рівнях. При цьому враховано як особливості засвоєння і використання дієслівної лексики цими дітьми, так і принцип логопедичної тераностики, який полягає у застосуванні діагностичних методик із терапевтичною метою; такий підхід сприятиме розв'язанню проблеми єдності діагностики та корекції у логопедичній роботі. Запропоновано окремі методичні вказівки щодо актуалізації дієслівного словника у дошкільників із загальним недорозвиненням мовлення, щодо вмінь дітей відображати смислові зв'язки дієслів у словосполученнях, щодо розвитку вмінь дієслівної сполучуваності та вмінь контекстуально-дисреренційного вживання дієслів.

Ключові слова: загальне недорозвинення мовлення, дошкільники, дієслівний словник, лексична семантика дієслів, граматична семантика дієслів, граматико-синтаксичні зв'язки, дієслівні словосполучення.

The article is devoted to the problem of forming the verb part of the lexical component in preschoolers with general speech underdevelopment. Semantic and methodological aspects of speech therapy work on normalization of verb vocabulary in these children have been developed. The importance of verb vocabulary for the development of semantic components of speech, syntactic structures and content of children's speech is emphasized.

Typical features of verbal vocabulary acquisition by children with speech underdevelopment are determined: violation of distinction of semanticgrammatical forms of verbs, situational verbal and gestural substitutions of verbs, narrowing of semantic field of verbs, difficulties of realization of syntactic connections of verbs in utterances. The modern criteria for diagnosing vocabulary of children with general speech underdevelopment are analyzed and their content in relation to verb vocabulary is specified; the importance of formation assessing of grammatical forms of verbs (generic, specific, etc.), semantic (prefixal, suffixal), lexical-semantic forms of verb synonyms, antonyms ambiguity, etc.; skills of lexical control in the process of verbs using. The content of verb vocabulary formation in preschoolers with general speech underdevelopment is developed. This is the accumulation of verb tokens, taking into account the grammatical category of the verb as part of speech; development of understanding and use of derivational meanings of verbs caused by word-forming morphemes; formation of lexical and semantic forms of verbs; formation of lexical control operations at the morphological and semantic levels. This takes into account both the peculiarities of learning and use of verbal vocabulary by these children, and the principle of speech therapy theranostics (a combination of diagnostic and therapy), which consists in the use of diagnostic techniques for therapeutic purposes; this approach will help solve the problem of unity of diagnosis and correction in speech therapy.

Some methodical instructions on actualization of verb vocabulary in preschoolers with general speech underdevelopment, on children's ability to reflect semantic connections of verbs in phrases, on development of verb compatibility skills and skills of contextual-differential use of verbs are offered.

Key words: general speech underdevelopment, preschoolers, verb vocabulary, lexical semantics of verbs, grammatical semantics of verbs, grammatical-syntactic connections, verb phrases.
Кам'янець-Подільського національного університету імені Івана Огієнка
Постановка проблеми в загальному вигляді. Мовленнєвий розвиток дитини з раннього віку опосередкований процесом накопичення знань та уявлень про навколишнє. Спілкуючись із дорослими, дитина сприймає вербальну інформацію про навколишню дійсність і тим самим поступово засвоює лексичні засоби - слова для позначення предметів, дій, станів, якостей, ознак, простору, часу тощо. Надалі сприйнята та засвоєна лексика слугує дитині для відображення її власних знань та уявлень про картину світу.

Система лексичних засобів (лексичний компонент мови і мовлення) є важливим чинником розвитку у дитини понятійного (вербального) мислення, 
адже малюк поступово опановує різні семантичні значення слів (конкретні чи ситуативні, контекстуальні, переносні, узагальнені; протилежні, подібні, багатозначні; родові, числові, часові та ін.).

Важлива роль серед компонентів лексичної системи належить словам для позначення дій та процесів - дієсловам. Як граматична одиниця української мови дієслово характеризується складністю та різноманітністю, оскільки володіє розгалуженою системою граматичних категорій i граматичних фоорм. Лінгвістами, психолінгвістами, фрілологами відзначається така характеристика української мови, як «дієслівність» (предикативність), адже семантичним центром висловлювання виступає дієслово, від якого утворюються смислові зв'язки. Значення дієслівної лексики полягає, безперечно, у тому, що дієслова організують синтаксичну структуру висловлювань, мають найбільше смислових зв'язків у реченнях і загалом створюють умови для виникнення зв'язного мовлення [13, с. 138-159].

За наявності загального недорозвинення мовлення (далі - ЗНМ) у дітей порушується процес засвоєння лексичного компоненту, зокрема системи лексичних значень [2; 10]. Страждають фрункції предметної та понятійної співвіднесеності слів, виявляється слабка орієнтація у змістовному боці слів, характер лексичних значень залишається тривалий час дифузним і нестійким, обсяг семантичних полів є обмеженим [3, с. 49-51]. Дієслівна лексика не $є$ винятком: типовими недоліками її засвоєння дитиною із ЗНМ є жестові заміни дієслівних лексем (показ, жестова імітація замість називання), пропуски дієслів у словосполученнях та реченнях, змішування значень дієслів за фрункціональною чи фронетичною ознакою, недоліки у розрізненні дієслівної семантики у цілому [7]; мовлення дитини із ЗНМ утрачає змістовність, смислову наповненість.

Аналіз останніх досліджень і публікацій. Семантику дієслова науковці вивчали 3 позицій мовознавства, психології мовлення та комунікації, а також у контексті мовленнєвого розвитку дитини, зокрема лексичного компоненту. Ними було визначено, що цей складник лексичного компоненту позначає процес, який має певні часові показники: початок процесу, ознаку закінченості, тривалість та нетривалість (В. Русанівський, 1986); деталізовано лексико-семантичні характеристики дієслова як частини мови (М. Лукач, 2014); описано зв'язок семантичних характеристик дієслів із граматичними або словотворчими елементами (М. Лукач, 2014; Н. Костишин, 2005; І. Вихованець, М. Плющ, К. Городенська, 1988 та ін.); розглянуто дієслівнопредикативну лексику як детермінант зв'язного висловлювання в онтогенезі дитячого мовлення (С. Цейтлін, 2000); проаналізовано залежність процесу засвоєння дієслів від здійснюваної дити- ною предметно-практичної та ігрової діяльності (О. Гвоздєв, 2007; М. Жинкін, 1958; О. Леонтьєв, 1965).

Дослідження дієслівної ланки у мовленні у дітей із ЗНМ здійснювалися у напрямі діагностики лексичних умінь (розуміння і вживання дієслів у мовленні) та у напрямі фрормування у цих дітей лексичних умінь і фрразового мовлення загалом.

Зокрема, діагностичне вивчення мовленнєвої діяльності середніх та старших дошкільників із ЗНМ показало, що цим дітям властиві труднощі розрізнення значень афріксальних дієслів (Г. Грибань 2005; Л. Трофріменко, 2012); порушення сприймання значень завершеності дії та відтінків значень дій (Л. Трофріменко, 2013); заміни назв дій словами, близькими до ситуації та зовнішніх ознак (В. Гончарова, 2005); переважання інтуїтивно-практичної стратегії сприймання значення дієслова через призму власного досвіду та індивідуальних уявлень про навколишнє (О. Мілевська, 2020); малий обсяг семантичного поля дієслів, що проявляється в обмеженій кількості значеннєвих зв'язків (Є. Соботович, 2003; Л. Трофріменко, 2007; Г. Грибань, 2005); важкодоступність у сприйманні та засвоєнні дієслівної антонімії та синонімії (Л. Трофріменко, 2007); наявність структурного аграматизму, який виявляється у порушенні синтаксичних зв'язків дієслова (предиката) з іншими структурно-синтаксичними одиницями висловлювання (В. Гончарова, 2005).

Окремим предметом уваги науковців були аспекти корекції лексичних умінь у цілому та у дієслівній ланці зокрема. Було здійснено науково-теоретичне обґрунтування змісту і послідовності корекційної роботи з формування дієслівної лексики у дошкільників із ЗНМ (Є. Соботович, 2005; Л. Трофріменко, 2007; 2013); визначено, що результативність засвоєння дітьми із ЗНМ дієслівної семантики залежить від продуманого добору самої дієслівної лексики (передусім особистісно значимої) (Є. Кузнєцова, І. Тихонова, 2005); наголошено на важливості дотримання діяльнісного принципу навчально-корекційної роботи у цьому напрямі (Н.Ніщєва, 2004).

Виділення не вирішених раніше частин загальної проблеми. Значимість дієслівної лексики для розвитку синтаксичної структури висловлювань, для змістового боку мовлення у цілому, роль дієслів у динаміці понятійного мислення дитини та, з іншого боку, специфіка засвоєння дітьми із ЗНМ дієслівної лексики об'єктивують потребу поглибленого вивчення проблеми опанування дітьми вказаної нозології дієслівним вокабуляром та водночас скеровують у русло розроблення змістових аспектів та їх методичного наповнення щодо формування у дітей із ЗНМ знань та вмінь практичного використання дієслівної семантики. 
Мета статті. Мета статті полягає у визначенні змістових засад логопедичної роботи з фрормування дієслівної лексики у дошкільників із загальним недорозвиненням мовлення.

Виклад основного матеріалу. Чимало дослідників дитячого мовлення, у т. ч. психологів, лінгвістів, психолінгвістів, зазначають, що становлення лексичної семантики в онтогенезі має специфріку у послідовності засвоєння лексики на імпресивному та експресивному рівнях (праці О. Гвоздєва, М. Жинкіна, О. Леонтьєва, С. Цейтлін, Г. Ляміної, Т. Ушакової, О. Шахнаровича та ін.). Зокрема, в активному мовленні дитини спочатку з'являються іменники, потім дієслова, хоча на імпресивному рівні відповідні лексичні значення дитина починає засвоювати інакше: її увагу спочатку привертають назви дій або назви тих предметів, з якими дорослий знайомить дитину через процес виконання (демонстрації) дій із ними (М. Жинкін, 1958; С. Цейтлін, 2000). Цю особливість науковці пояснюють тим, що дієслова більшою мірою наповнені особистісно значимим смислом і мають для дитини конкретизоване значення $[1 ; 4 ; 13 ; 15]$. Зокрема, це лексеми, які позначають активні, візуалізовані стани чи дії (спить/спати, їсть/їсти, купатися, гуляти, кусає/кусай, їд, біжить, читає, плаче та ін.), більшість з яких дитина може самостійно виконати та, відповідно, сприйняти й осмислити на рівні особистого досвіду.

У дошкільників із ЗНМ спостерігається недостатня активність засвоєння та вживання дієслівної лексики. Певною мірою ця особливість пояснюється тим, що більшість слів-назв дій, презентованих дитині дорослим, супроводжуються відповідними жестами: для дієслова їсmи - жест, який імітує рух руки з ложкою, піднесеною до рота, та жест-імітація прийняття їжі у ротову порожнину та жування; для дієслова різати - жест рукою, який імітує рухи з ножицями чи ножем, тощо. Тому тривалий час зберігається значна різниця між кількісним складом активного і пасивного словника дієслів. Особливу трудність становить актуалізація (пригадування, добір) дієслівних лексем. Натомість частими $€$ мімікожестові заміни дієслів.

У дослідженнях В. Гончарової [2, с. 419], Г. Грибань [3], Л. Трофріменко [12, с. 31-32], Н. Жукової та інших науковців висвітлено якісну характеристику словника дієслів у дітей із ЗНМ. На переконання дослідників, це переважно назви тих дій, які дитина щодня виконує (вмиватися, їсти, спати, ін.) або спостерігає у дорослих. У мовленні цих дітей присутні ситуативні лексичні заміни назв дій назвами предметів (спати $\rightarrow$ ліжко, відкриває $\rightarrow$ двері, росте $\rightarrow$ дерево, ін.) або функціональні дієслівні заміни (біжить $\rightarrow$ йде, шиє $\rightarrow$ в'яже, варить $\rightarrow$ смажить, пише $\rightarrow$ малює, ін.). Іх труд- нощами діти із ЗНМ добирають дієслова-синоніми, антоніми; антонімія утворюється ними зазвичай шляхом приєднання до дієслова заперечної частки «не»: «смітить $\rightarrow$ не смітить» замість «прибирає» тощо. Тобто дошкільникам із ЗНМ властиві порушення у засвоєнні і використанні дієслівної семантики [6, с. 153-154; 7, с. 339-341].

Зазначимо, що, відповідно до сучасних методичних положень щодо логопедичної корекції, обов'язковою є попередня діагностика фрактичного рівня сорормованості певних мовленнєвих умінь у дитини 3 мовленнєвим недорозвитком. Нами був проведений аналіз науково-методичної літератури (праці Г. Грибань, Є. Соботович, Л. Трофріменко, Н. Чепелюк та ін.), на основі якого було визначено основні критерії оцінки стану сформованості словника та конкретизовано їх зміст стосовно дієслівної лексики [3, с. 47-48; 9, с. 4; 11; 13]:

- достатній розвиток родових і числових фрорм дієслів; особових фрорм дієслів; видових категорій дієслів;

- розуміння дериваційного значення дієслів (із різними за значенням морфемами);

- засвоєні лексико-семантичні явища (добір антонімічних пар; добір синонімів; диоеренціація близьких за значенням дієслів; розуміння багатозначності дієслів);

- сорормованість лексичного контролю (на морфологічному і смисловому рівнях).

Керуючись цими діагностичними критеріями та спираючись на принцип логопедичної тераностики (за P. Dobson, 2010; S. Warner, 2004; В. Тищенко, 2016), який передбачає використання діагностичних методик як терапевтичних [11], а також ураховуючи труднощі актуалізації дієслівної лексики та недостатність кількісного й якісного складу дієслівного словника у дошкільників із ЗНМ, уважаємо за доцільне визначити змістові аспекти формування дієслівної семантики у дошкільників із ЗНМ:

1. Розширення (уточнення, накопичення) дієслівного словника та фрормування граматичної семантики дієслова (приналежність до категорій роду, числа, особи, виду (доконаний, недоконаний), відмінка, часу, способу (дійсний, наказовий, умовний, ін.)), фрорм безособовості та зворотності.

2. Формування дериваційної семантики дієслова (префіксальної, суфріксальної, префріксально-суфріксальної).

3. Формування лексичної семантики дієслова (понятійної співвіднесеності, протилежності значень, подібності значень, багатозначності).

4. Відпрацювання операцій лексичного контролю (верифікація вживання дієслова відносно контексту з візуальним підкріпленням та без нього).

Узагальнення викладеного вище дає підстави сорормулювати такі методичні вказівки щодо фрормування дієслівної семантики у дошкільників із загальним недорозвиненням мовлення: 
- передусім потрібно відпрацювати навички актуалізації словника дієслів, оскільки, з одного боку, вони $€$ базовими мовленнєвими операціями лексичного рівня, а з іншого - саме ці навички виявляються порушеними за наявності ЗНМ. Для оптимізації процесу актуалізації дієслівної лексики варто активізувати вміння дітей орієнтуватися на дієслівну семантику; зосередити увагу на лексико-семантичних ознаках дієслів (синонімія, антонімія, багатозначність ін.). Доречними будуть завдання з візуальним підкріпленням, без візуального підкріплення (слухове сприймання), 3 демонстрацією або імітацією дії; робота над категоріальним і контекстуальним значенням дієслова;

- окремої уваги потребує розвиток у дошкільників із ЗНМ мовленнєвих умінь відображати смислові зв'язки, залежності у словосполученнях та реченнях, адже дієслова є основою їхнього змісту, від їх адекватного вживання великою мірою залежать внутрішня семантика висловлювання та семантичні відтінки (чіткість) висловлювань. Наприклад, до різних номінативних понять (іменників) можна вжити однакові предикативні поняття (дієслова): «дощ йде, падає», «сніг йде, падає». Поряд із цим окремі предикативні поняття можуть бути використані лише диференційовано: «дощ ллється»; «сніг сиплеться»;

- не менш важливим $є$ фрормування дієслівних словосполучень та розвиток валентності (тобто сполучуваності) дієслова на основі граматичної та смислової узгодженості, зокрема узгодження дієслова з іменником у відмінку без прийменника та $з$ прийменником. Водночас така робота, на нашу думку, сприятиме виробленню у дітей із ЗНМ практичних навичок синтаксичної трансорормації та операцій лексико-семантичного контролю. Наприклад: орієнтовна лексика - одягати, шапка, голова, куртка; варіанти дієслівних словосполучень:

1) «одягаю шапку» (відмінкова фрорма іменника без прийменника);

2) «одягаю на голову» (відмінкова фрорма іменника з прийменником);

3) «одягаю шапку на голову» (розширення синтаксичного конструкту шляхом граматико-смислового узгодження номінативних лексем);

4) «одягаю на голову шапку" (трансорормація синтаксичного конструкту шляхом зміщення смислового акценту);

5) «одягаю куртку»; «одягаю куртку на голову» (тут останнє словосполучення використовується з метою верифрікації - виявлення дитиною відповідності змісту висловлювання);

- $з$ огляду на об'єктивну складність у засвоєнні дітьми із ЗНМ умінь контекстуально-диференційного вживання дієслів, необхідна спеці- альна робота 3 розвитку навичок поєднувати однакові номінативні лексеми з різними дієслівними та, навпаки, однакові дієслівні 3 різними номінативними: напр., «хлопчик спить, читає, малює, прибирає»; «спить дівчинка, котик, мама», ін.

Висновки. Отже, дієслівна лексика великою мірою детермінує процеси становлення смислових компонентів мовлення, опосередковує розвиток синтаксичних структур, надає змістовності мовленнєвим висловлюванням. Урахування значимості дієслівної лексики, виявлення особливостей опанування дієслівної лексикиу дошкільників із ЗНМ та визначення на цій основі змістових та методичних аспектів логопедичної роботи з фрормування дієслівної лексики у дітей указаної категорії $€$ необхідними умовами здійснення корекційної-розвивальної роботи стосовно підвищення рівня їхньої мовленнєвої компетентності.

Проведене нами дослідження не вичерпує усіх аспектів означеної проблеми. Перспективою $€$ розроблення методичного наповнення (змісту корекційних завдань, супровідних матеріалів) відповідно до визначених змістових напрямів фрормування дієслівної лексики у дошкільників із загальним недорозвиненням мовлення.

\section{БІБЛІОГРАФІЧНИЙ СПИСОК:}

1. Гвоздев А.Н. Вопросы изучения детской речи. Санкт-Петербург : Детство-пресс, 2007. 472 с.

2. Гончарова В.А. Динамика усвоения структуры значения слов детьми с нормальным и нарушенным речевым развитием. Онтогенез речевой деятельности: норма и патология. Москва : Прометей, 2005. C. 418-426.

3. Грибань Г.В. Дослідження особливостей оволодіння дієслівної лексикою молодшими школярами з ТВМ. Теорія і практика сучасної логопедії. 2005. Вип. 2. С. 47-53.

4. Жинкин Н.И. Механизмы речи. Москва, 1958. $378 \mathrm{c}$.

5. Лукач М.О. Лексико-семантична класифікація дієслів української мови. Наукові записки Національного університету «Острозька академія». 2014. Вип. 46. С.106-108.

6. Мілевська О.П. Особливості семантичної домінанти сприймання слова у дітей із загальним недорозвиненням мовлення. Актуальні питання корекційної освіти (педагогічні науки). 2020. № 15. C. $146-154$

7. Мілевська О.П. Дослідження дієслівної семантики у молодших школярів із загальним недорозвиненням мовлення. Materials of the $X X X$ the Intern. Science Conf. "Interaction of society and science: problems and prospects», London, England (June 15-18, 2021). p. 334-341.

8. Русанівський В.М. Структура українського дієслова. Київ : Наукова думка, 1986. 96 с.

9. Соботович Є.Ф. Критерії оцінювання мовленнєвого розвитку дитини (у його лексичній ланці) на 
різних вікових етапах. Десректологія. 2003. № 2. C. 2-7.

10. Соботович Є.Ф. Формування семантичної структури слова у дітей з вадами мовленнєвого розвитку Теорія і практика сучасної логопедії. 2005. Вип. 2. С. 3-17.

11. Тищенко В.В. Логопедична тераностика: концепт нового напряму діагностики та корекції мовленнєвих порушень. URL: https:// aqce.com.ua/vypusk-7-t-1-t-2/ticshenko-vv-logopedichnateranostika-koncept-novogo-naprjamu-diagnostiki-takorekcii-movlennjevih-porushen.html.
12. Трофріменко Л.І. Шляхи подолання загального недорозвитку мовлення у дітей дошкільного віку : монограсрія. Київ, 2012. 144 с.

13. Цейтлин С.Н. Язык и ребенок: Лингвистика детской речи. Москва : ВЛАДОС, 2000. 240 с.

14. Чепелюк Н.І. Збагачення словникового запасу учнів початкових класів дієслівними формами : автореф. дис. ... канд. пед. наук. Одеса, 2001. 30 с.

15. Шахнарович А.М. Психолингвистический анализ семантики и грамматики: на материале онтогенеза речи. Москва : Наука, 1990. 166 с. 